\title{
MIOSPORES AND DINOFLAGELLATES BIOZONATION AND PALEOECOLOGICAL ANALYSIS OFTHE SUBSURFACE LOWER CRETACEOUS SUCCESSIONIN NORTH WESTERN DESERT, EGYPT.
}

\author{
Abdel Galil A. Hewaidy ${ }^{1}$, Abdel HakamBaioumi ${ }^{2}$, Walid A.Makled ${ }^{2}$ and Mohamed M. El Garhy ${ }^{1}$ \\ 1 Geology Department, Faculty of Science, Al-Azhar University. P.O.Box 11884, \\ 2 Egyptian Petroleum Research Institute (EPRI), Nasr City, Cairo, Egypt.
}

\begin{abstract}
A palynological analysis has been carried out on the Lower Cretaceous Kharita, Dahab, Alamein and Alam El Bueib formationsencountered in the subsurface sections of the Mamura-1 (MAX-1), Mersa Matruh-1 (MMX1) and Burg El Arab-1(BAX-1) wells, north Western Desert of Egypt. 144 core samples have been analyzed palynologically and produced 147 species belonging to 102 genera, which allow and recognizing three informal sporomorph zones and two informal dinoflagellate zones are restricted to northern Western Desert ranging from Neocomian to Albian ages. They are correlated with the well-documented biozonations established for the same interval from other localities in the north Western Desert of Egypt and northern Gondwana regions. According to the relative abundances and paleoecologic characters of the palynomorphs, the Kharita Formation maybe deposited in an open-marine, warmer and humid climate. The Dahab and Alamein formations maybe deposited in a shallow to inner shelf environment and under humid, tropical to sub-tropical climatic conditions. The Alam El Bueib Formation maybe deposited in deltaic; warmer environment under humid climatic conditions.
\end{abstract}

Keywords: Kharita Formation., Alamein Formation., Dahab Formation., Alam El Bueib Formation., palynostratigraphy, paleoecology, Western Desert, Egypt.

\section{INTRODUCTION}

The north Western Desert of Egypt has a great economic importance because it confines some major hydrocarbon fields. The successful evaluation of petroleum system and sedimentary basin request a comprehensive analysis of the subsurface data from cutting or core samples to reach to precise age and paleoecology of the evaluated units. This information is gained by using mostly microfossil investigations such as palynomorphs which are considered as a very good tool to achieve previous requests.

The palynomorphs biozonation or palynostratigraphy of north Western Desert has been extensively studied over the last four decades especially on the subsurface materials (Saad and Ghazaly, 1976; El Shamma 1988; Makled et al, 2013; Ied and Lashin 2016). The palynostratigraphy of the Mersa Maruh-1 well was investigated before by Sultan 1987, Penny
1988 and 1991 and El Beialy 1994. This paper aims to determine the age of the Kharita, Dahab, Alamein and Alam El Bueib formations and to verify paleoecological conditions during their deposition. The use of the core materials is an advantage of the present study compared to the previous studies.

\section{MATERIAL AND METHODS:}

The core samples are picked from wells, Mamoura-1(MAX-1)(26ㅇ 1521 E,31 3004 N), Mersa Matruh-1(MMX-1) (27 1607 E, $31^{\circ} 19$ $43 \mathrm{~N})$ and Borg El Arab-1(BAX-1) (29 3128 E, $30^{\circ} 5520 \mathrm{~N}$ ) as arranged from the west to the east,Fig.1. The core samples are separated into different core sets and each set belongs to a single core. In MAX-1, there are 46 core samples that are distributed over 11 core sets. In MMX-1 well, there are 34 core samples that are distributed into 11 core sets. In the BAX-1, there are 64 core samples that are distributed over 8 core sets. The core sets are distributed 
more or less evenly through the thickness of the Lower Cretaceous section from the studied wells. These samples were prepared with the palynological technique, which involves the subsequent acid digestion by hydrochloric and hydrofluoric acids (Traverse 1988). The residue is glowed directly to a slide after sieving with 10-micron mesh sieve. 200 individual species were counted for the palynostratigraphic purposes. All slides were microscopically examined under a transmitted light microscope (a Lieca microscope). The encountered palynomorphs are examined, identified and representative forms are photographed. The palynomorphs are identified and arranged in three plates (plates 1-3).

\section{Stratigraphic setting:}

In this study, the Early Cretaceous interval is subdivided into four formations Kharita, Dahab, Alamein, Alam El Bueib of which Alam El Bueib and Matruh (shale) formations are equivalent to each other, Alam El Bueib towards east and Matruh shale towards west. The arrangement of these formations from older to younger is as follows:

\subsection{Alam El Bueib Formation:}

The Lower Cretaceous (Neocomian Barremian) is represented in the studied wells by Matruh (shale) Formation in the western part of the north Western Desert and Alam El Bueib Formation in the eastern part of the north Western Desert. The Alam El Bueib Formation is composed of sandstone unit with frequent shale interbeds in its lower part and occasional limestone beds in the upper part. These beds become thicker and abundant in the northwest (Hantar, 1990). In the studied wells, this formation is composed essentially of shale and frequent beds of limestone. Shale is characterized by dark grey to grayish brown color, hard compact fissile contains carbonaceous material and pyrite, while the limestone is detrital oolitic argillaceous and glauconitic, hard to very hard and of dark grey color and with thin intercalations of calcareous shale. The thickness of this formation in BAX1 well extends between 11643 and 8371 feet (thickness 372 feet), Fig. 2. In MMX-1 and MAX-1 wells, it is replaced by the coeval Matruh (Shale) Formation which composed of dark grey to grayish brown shale, hard compact fissile contains carbonaceous material and pyrite and frequent beds of limestone detrital oolitic argillaceous and glauconitic, hard to very hard and of dark grey color and with thin intercalations of calcareous shale between 14401 and 7875 feet (thickness 6526 feet) and between 7875 and 9675 feet (1820 feet thickness) respectively, Figs. 3 and 4.

\subsection{Alamein Formation:}

The Alamein Formation is widespread unit in the northern part of the Western Desert despite it thins in most of the studied wells. In its type section in Alamein -1 well, it extends between 8441 and 8166 feet (275 feet thickness) and contains mainly, light brown hard microcrystalline dolomite (Hantar, 1990). In the studied wells, it encloses dolomite with sandstone and shale alternating with thin lamina and irregular lenses of sandstone. Shale is dark grey to black, brownish in part rarely pyritic, while sandstone is fine - medium grained, friable, sub - angular to sub - rounded, silty in part and pyritic. Alamein Formation is represented in MMX-1 well at depths between 7405 and 7875 feet (470 feet thickness), Fig. 4. In MAX-1 well, it is represented at depths between 7500 and 7875 feet $(375$ feet thickness), Figs. 3 and it is missing in BAX-1 well, Figs. 2. It rests on the Alam El Bueib Formation in MMX-1 and MAX-1 wells. This formation is at its maximum thickness in Alamein Basin as well as the underlying Alam El Bueib Formation.

\subsection{Dahab Formation:}

The Dahab Formation is widespread in the northern Western Desert. In it type section in Dahab-1 well, it ranges from 10433 to 11000 feet (567 feet thickness) and it includes grey to greenish grey shale unit with thin interbeds of 


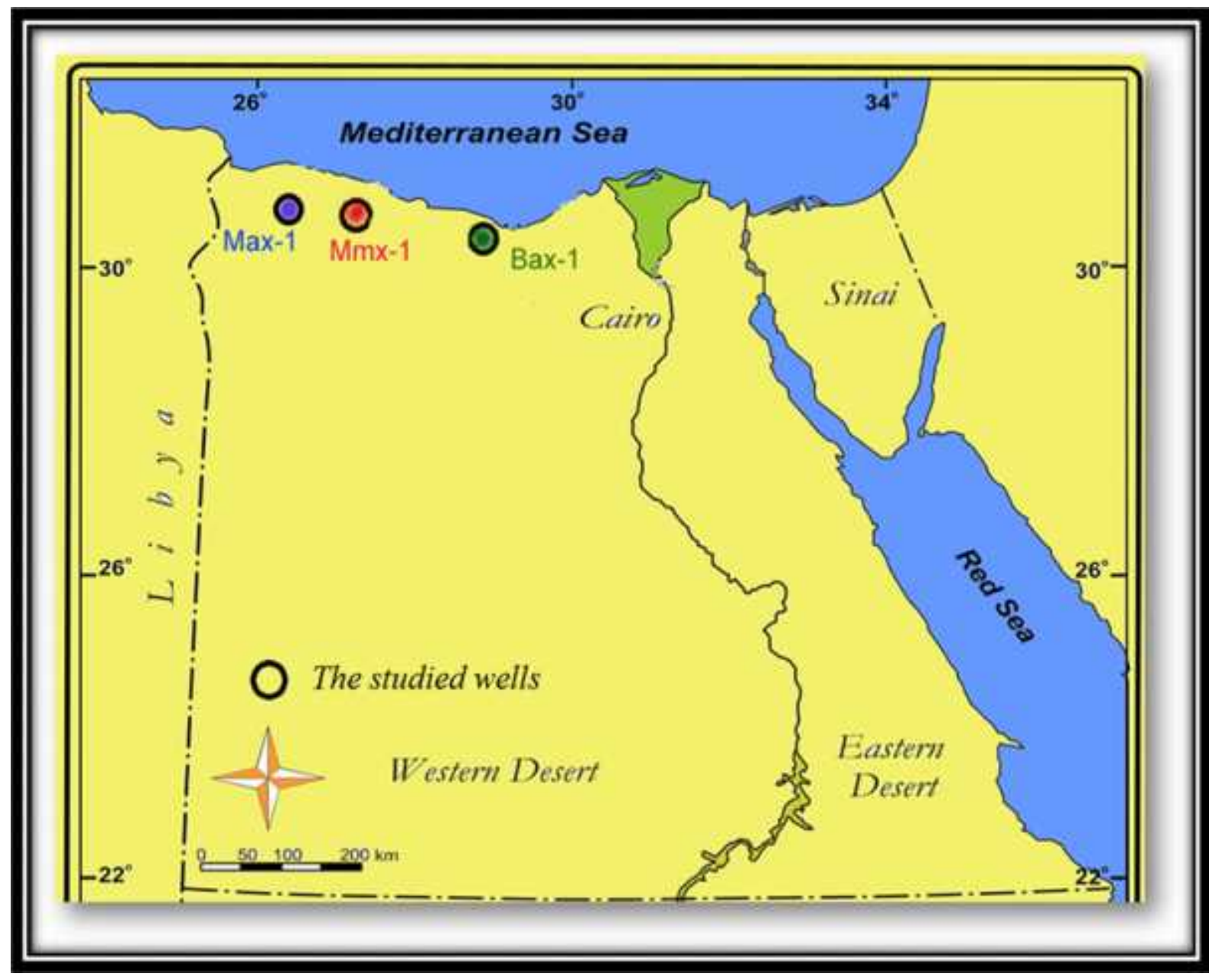

Fig.1. Location map of the studied wells.

siltstone and sandstone (El-Gezeery and O Conner, 1975). In the studied wells, the Dahab Formation is composed of dark brown to dark grey, compact, slightly silty shale alternating with thin lamina and lenses of sandstone stringers which characterized by grey color and fine grained particles. The Dahab Formation is represented at MAX-1 well at depths between 5894 and 7500 feet (1606 feet thickness), Fig.3, and in BAX-1 well at depths between 7200 and 8371 feet (1171 feet thickness), Fig.2, whereas in MMX-1 well at depths between 4778 and 7875 feet (3097 feet thickness), Fig.4.

\subsection{Kharita Formation:}

The Kharita Formation is one of the prominent formations in the northern Western Desert. In its type section in Kharita -1 well, this formation reaches 1276 feet thickness and is composed mainly of fine to coarse grained sandstone with subordinate shale and carbonate interbeds (Hantar, 1990). In the studied wells, it is composed mainly of dark grey fissile splint shale with carbonaceous matter and well cemented, well sorted medium grained sandstone with clay fragments and clayey, detrital hard well cemented, glauconitic limestone. This formation is represented in MMX-1 well at depths between 2161 and 4778 feet (4617 feet thickness), in BAX-1 well at depths between 5842 and 7200 feet (1358 feet thickness) and in MAX-1 well at depths between 4021 and 5894 feet (1873 feet thickness), Figs. 2-4. 


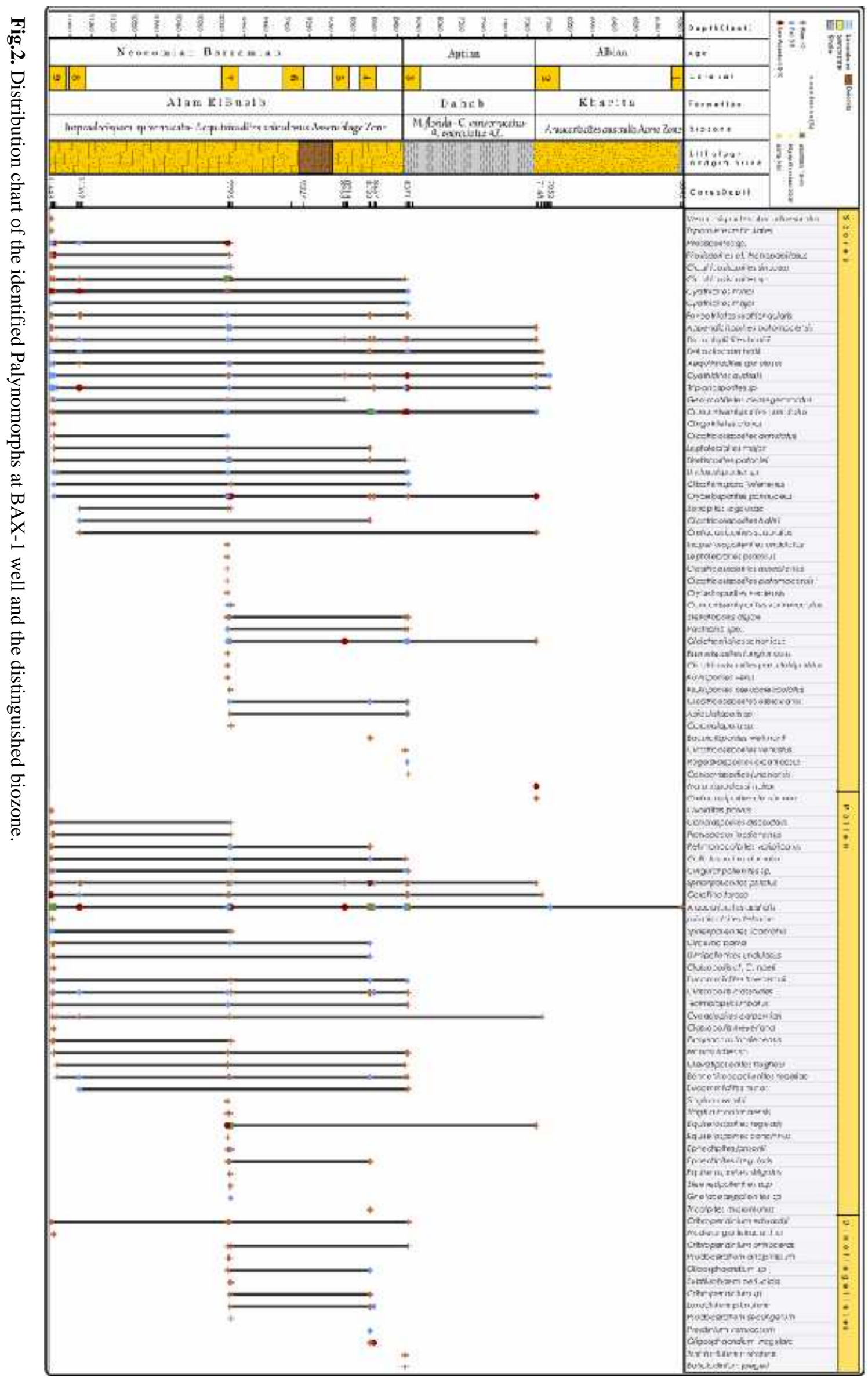




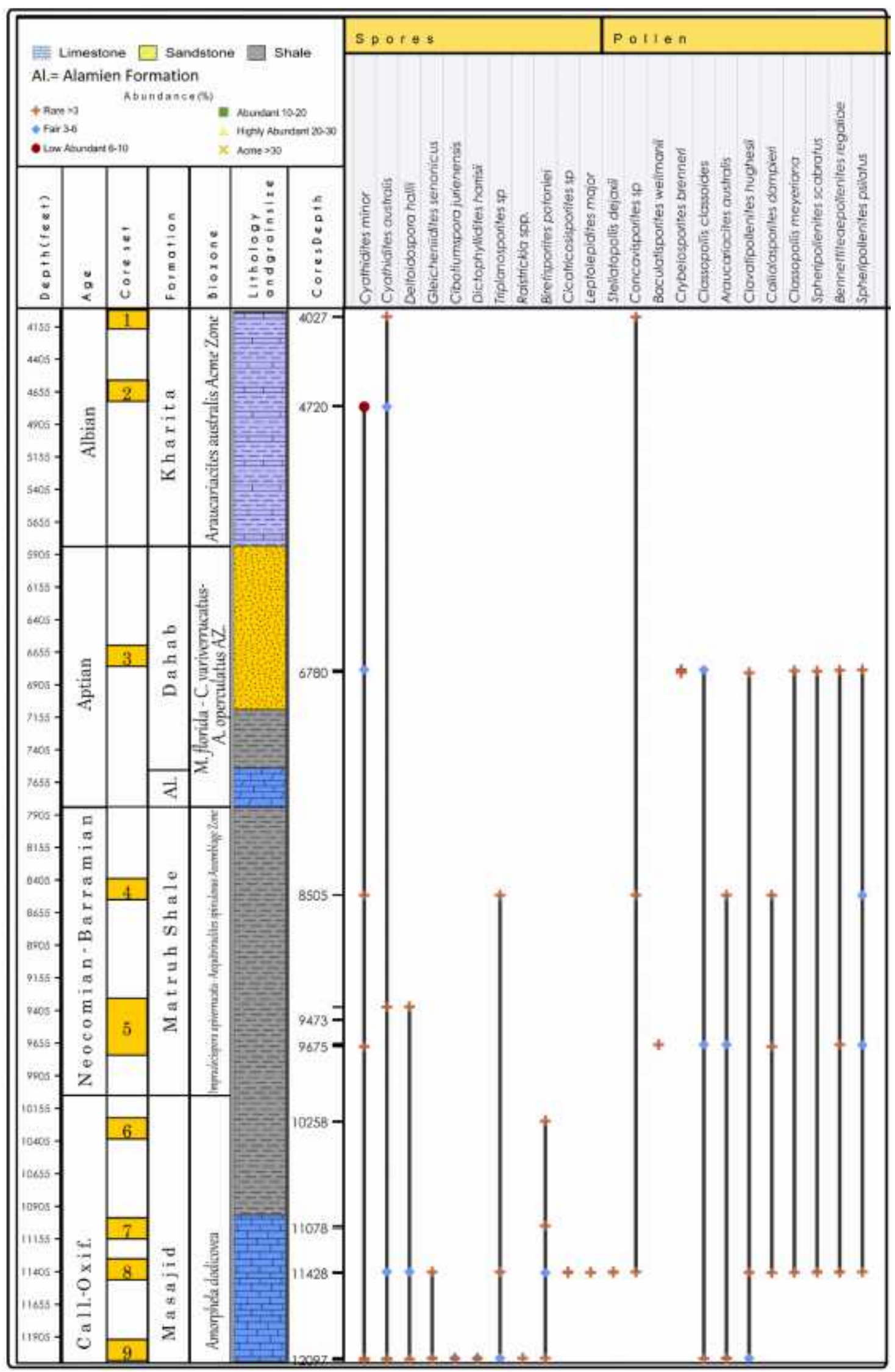

Fig.3.Distribution chart of the identified Palynomorphs at MAX-1 well and the distinguished biozone 


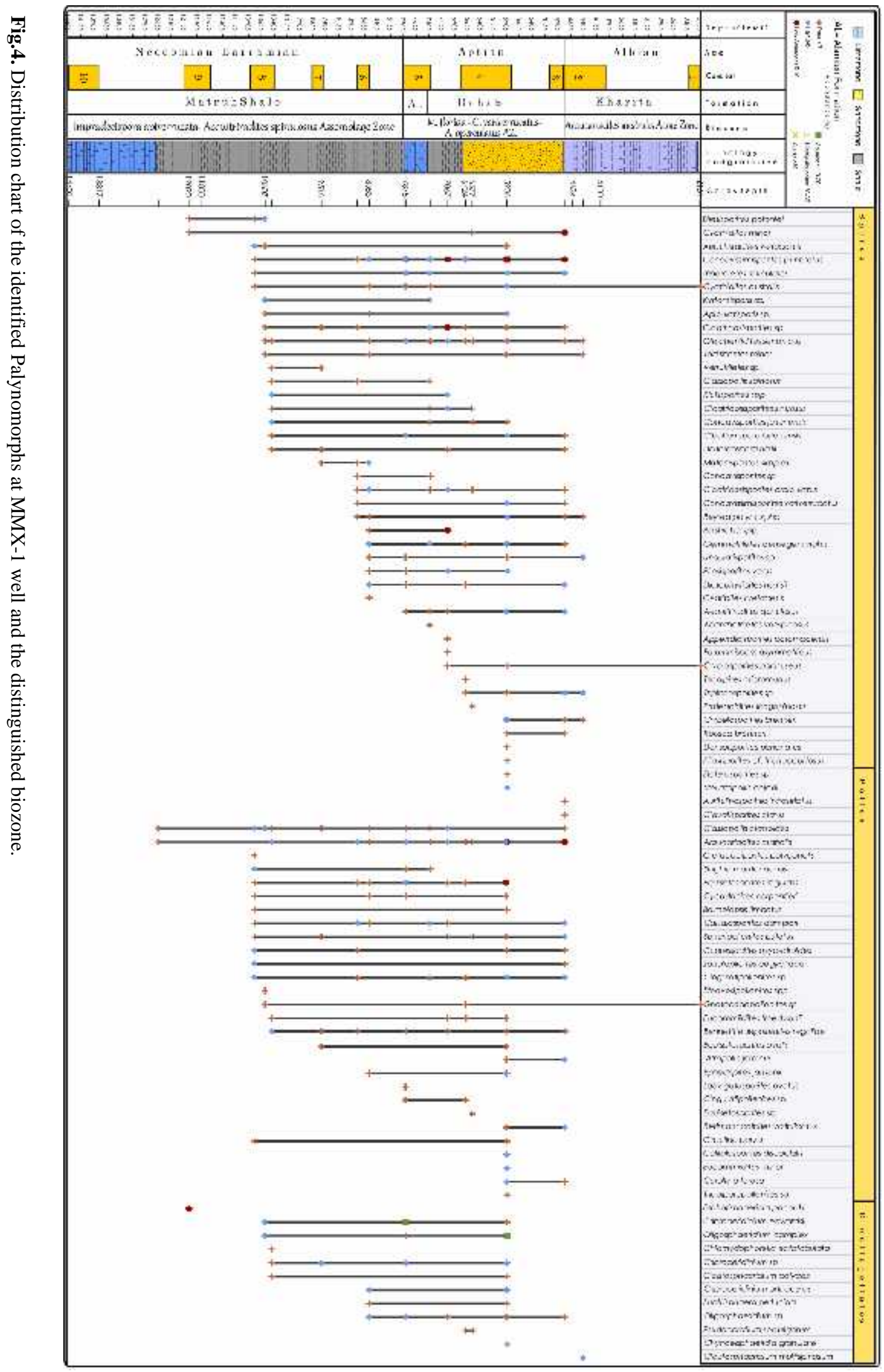




\section{Palynostratigraphic zones:}

The palynostratigraphy of the Lower Cretaceous (Neocomian - Albian) Kharita, Dahab, Alamein, Alam El Bueib formations at MAX-1, MMX-1 and BAX-1 wells is discussed here. The palynostratigraphy ofMAX-1 and BAX-1is presented here for the first time. In the present work, the palynomorphs biozonation relied on the miospores scheme of Makled, 2004. In this scheme the Lower Cretaceous succession is divided into 7 miospore zones that extend from the Berriassian to Early Cenomanian. Consequently, three miospore zones and two dinoflagellate zones are identified and discussed in this study. The stratigraphic ranges of the identified taxa are presented in figures 2 , 3 and 4. From the examination of core samples, there were 147 palynomorph species identified in the present study. The following biozones are defined in the three boreholes.

\section{M7: Impradecispora apiverrucata-} Aequitriradites spinulosus Assemblage Zone

Definition: This zone is defined by the occurrence of Aequitriradites spinulosus, Impradecispora apiverrucata and Pilosisporites trichopapillosus.

Occurrence: This zone is represented by the core sets 4-9 (8657-11643 feet, 2986 feet thickness) in BAX-1 well, core sets 6-10 (14410-8585 feet, 5825 feet thickness) in MMX-1 and core sets 4-6 (10252-8502 feet, 1750feetthickness) in MAX-1.

Age diagnosis: This zone is well recorded in the subsurface Berriasian - Barremian in the Western Desert and Aequitriradites spinulosus is used generally as spore indicator for these ages in Egypt (Makled, 2004; Makled et al., 2013, Tahoun et al., 2015). Aequitriradites spinulosus is accepted as an Early Cretaceous (Berriasian - Valanginian) marker spore in Egypt as discussed in details by Schrank and Mahmoud (1998) from the Lower Six Hills Formation. Impradecispora apiverrucata is considered as a Neocomian index form in Egypt, Libya and Sudan (Saad and Ghazaly, 1976; Aboul Ela, 1979; Schrank and Mahmoud,
1998). Baioumi (2002) identified assemblage of Impradecispora apiverrucata and Mudrongia simplex in Berriasian- Valanginian age. The recovered zone could be partially compared with zone of PS3 (Berriasian-Early Hauterivian) reported by Ibrahim and El Beialy, (1995). Bassiouni et al., 1992 pointed out that assemblage of Triloposporites apiverrucata (now Impradecispora apiverrucata) is of Valanginian-? early Hauterivian age and named it Pilosisporites trichopapillosus Assemblage Zone.Lower Cretaceous (? Berriasian), England (Norris, 1963). An assemblage of Pilosisporites trichopapillosus, Aequitriradites verrucosus Pilosisporites sp, Murospora florida, Appendicisporites tricornetatus, Triloposporites trioorticulosus and Impradecispora apiverrucata is mentioned to be typical of Valanginian-early Hauterivian age (Abdelmalik et al., 1981; Schrank, 1984, 1987, 1990, 1992; Thusu and Van Der Eem, 1985; Thusu et al., 1988; Kora and El Beialy, 1989; El Beialy et al., 1990; Bassiouniet al., 1992; El Shamma and Baioumi, 1993; Awad, 1994; Ibrahim and El Beialy, 1995 and Ibrahim and Schrank, 1996).

Correlation: this zone can be correlated with Impradecispora apiverrucata and Mudrongia simplex Assemblage Zone of Baioumi (2002) and can be correlated with PS3 zone oflbrahim and El Beialy (1995), Lower part of Assemblage Zone II of Mahmoud et al., (1999). Pilosisporites trichopapillosus Assemblage Zone of El Shamma and Baioumi(1993).

\section{M4: Murospora florida - Concavissimisporites variverrucatus- Afropollis operculatus Assemblage Zone}

Definition: This zone is defined by the occurrence of Murospora florida Concavissimisporites variverrucatus and Afropollis operculatus.

Occurrence: This zone confines the core set 3 (8392-8320 feet, 72 feet thickness) in the BAX-1, core set 3-5 (4798-7881 feet, 3083 feet thickness) in MMX-1 and core set 3 (6780- 
6759 feet, 21 feet thickness) in the MAX-1 well.

Age diagnosis: The assigned age of this zone is Aptian and it is assigned principally depending on the presence of Murospora florida, Concavissimisporites variverrucatus and Cicatricosisporites sinuosus as recorded in other regions in the Western Desert (Makled, 2004; Makled et al., 2014; Ied and Lashin, 2016).Murospora florida enter the local record from Aptian onward (Abdelmalik at al., 1981; Sultan, 1986; El Shamma and Arafa, 1988; Omranet al, 1990; Mahmoud, 1991; Bassiouni et al., 1992; Mahmoud et al., 1999; and Mahmoud and Moawad, 2000). A similar assemblage has been recognized by Mahmoud et al., (1999) dominated by the presence of Murospora florida, was given Aptian age. The assemblage of Murospora florida and Concavissimisporites variverrucatus has been attributed to the Aptian age by Mahmoud and Moawad, (2002). El Sheikh and Aly, (1994) recorded Murospora florida from early Aptian sediments of northern Sinai. El Shamma et al., 1997 and El Shamma et al., 1999 marked the increase of percentage ofMurospora florida in Aptian sediments. Schrank and Ibrahim, (1995) confirmed that Afropollis operculatus is an index form of the Aptian. El Shamma et al., 1999 marked the acme occurrence of Afropollis operculatus in Aptian age. Balmeisporites holodictyus, Cicatricosisporites sinuosus, Appendicisporites tricornetatus and Murospora florida strongly discriminate a distinctive Aptian assemblage (Abdelmalik et al. 1981; Sultan, 1986; El Shamma and Arafa, 1988; Omran et al, 1990; Mahmoud, 1991; Bassiouni et al., 1992; Mahmoud et al., 1999; and Mahmoud, Moawad, 2000).Pilosisporites veruswas recorded inAptian sediments in Argentina (Delcourt and Sprumont,1955).Kyrtomisporis $\mathrm{sp}$ is recorded in Aptian sediments of north Western Desert, Egypt (Omran et al. 1990). Pseudoceratium securigerum has a known range from early to Late Aptian in Egypt (Omran et al., 1990; El Beialy, 1994a; Schrank and Ibrahim, 1995; and Ibrahim et al., 1995). The base of the range of Subtilisphaera senegalensis is in the Lower Aptian sediments in NW Egypt (Schrank and
Ibrahim, 1995).Cribroperidinium orthoceras and Cribroperidinium edwardsii are distinctive markers for Aptian age (Omran et al., 1990; ElBeialy, 1994a; Schrank and Ibrahim, 1995; Ibrahim et al. 1995; El Shamma et al., 1997; El Shamma et al., 1999; Ibrahim et al., 2002).Oligosphaeridium complex, Subtilisphaera senegalensis, Odontochitina operculata, Pseudoceratium securigerum, Cyclonephelium vannophorum and Cribroperidinium orthoceras are considered to be of Aptian age (Omran et al., 1990; ElBeialy, 1994a; Schrank and Ibrahim, 1995; Ibrahim et al. 1995; El Shamma et al., 1997; El Shamma et al., 1999; Ibrahim et al., 2002).

Correlation and significance: This zone is correlated with the lower part of zone ps2 (Omran et al., 1990), It is similar to PS-1 of Mahmoud and Moawad (2002).This zone resembles Aptian Assemblage Zone III of Mahmoud et al. (1999), Murospora florida Assemblage Zone of El Shamma et al., 1997 and Murospora florida Acme Zone of El Shamma et al., 1999.Zone III (Aptian) of Mahmoud et al. (1999), in the Ramis-1X and Shaltut-1X wells, northern Western Desert and the Misri-1 well, northern Sinai, Egypt; PSI Zone (Aptian) of Mahmoud and Moawad (2002), in the Sanhur-1X borehole, northern Western Desert, Egypt; assemblages "A2" and "A3" (cores \#14 and \#15) of early-mid Aptian age of Ibrahim (2002), in the Ghazalat-1 well, northern Western Desert, Egypt equate to the lower part of this zone and Zone PSIII (Aptian) of Mahmoud and Deaf (2007) in the Siqeifa 1-X borehole, northern Western Desert, Egypt. The uppermost limit of this zone is coincided with the lower boundary of the Alamein Formation. This means that this zone is extended in the upper part of the Alam El Bueib Formation. In the present study, a similar hypothesis is found, that this zone extended in the upper part of Alam El Bueib Formation, which previously was given Barremian age by the drilling. The 
age of this upper part of Alam El Bueib Formation is reassigned to the Aptian age depending on the percentage of Murospora florida.

\section{M3: Araucariacites australis Acme Zone}

Definition: This zone is defined by the maximum occurrence of Araucariacites australis.

Occurrence: This zone covers the core sets 1 and 2 (5834-7188 feet, 1354 feet thickness) in the BAX-1, core set 1 and 2 (2161-4798 feet, 2637 feet thickness) in MMX1 and core set 1 and 2 (4021-4720 feet, 699 feet thickness) in the MAX-1 well.

Age diagnosis: This zone is well documented throughout the northern Western Desert to remark the Albian age (El Shamma et al., (1997); Bassiouni et al., 1992; El Shamma et al., 1999; Makled, 2004; Makled et al., 2013; Ied and Lashin, 2016).The absence of the early Cenomanian elaters (Elaterosporites, Elaterocolpites and Galeacornea) and the Aptian spores (Murospora) indicates the Albian age for these cores. El Shamma et al. (1997) recorded increase of gymnosperms specially Araucariacites australis in Albian age. Bassiouni et al. (1992) noted the obvious increase in number of Araucariacites australis in Albian. El Shamma et al. (1997) recorded that the uppermost occurrences of Scortea tecta and S. hamoza are of lower Albian age. El Shamma et al. (1999) identified the interval of Scortea tecta and S. hamoza in the Albian. Elaterosporites klaszi has its lowermost appearance in the middle part of the Albian stage in Africa and northern South America (Jardiné, 1967). Herngreen (1973) also reported the lowermost appearance of E. klaszi from Middle Albian sediments of Brazil. E. klaszi, Scortea tecta, S. hamoza and Crypelosporites pannuceus occur in of Albian sediments in many localities in the northern Gondowana Province (Herngreen, 1975) and Egypt (Omran et al., 1990). Dinopterygium cladoides has its lowermost appearance at the base of the Albian as recorded from Egypt (Omran, et al., 1990). It was also recorded from the Middle- Late Albian of France (Davey and Verdier, 1971; Foucher, 1980). An albian age is also supported by the absence of Aptian species Peseudoceratium securigerum. Subtilisphaera senegalensis was recorded from Albian sediments by many authors, (e.g. Omran et al., 1990; Schrank and Ibrahim, 1995; Ibrahim et al., 1995 and Ibrahim et al., 2002). Oligosphaeridium complex has its uppermost appearance in Albian age according to many authors (Omran et al., 1990; Bassiouni et al., 1992; Schrank and Ibrahim, 1995; Ibrahim et al., 1995 and Ibrahim et al., 2002). El Shamma et al. (1999) marked the interval of Oligosphaeridium complex in Albian age. The assemblage of E. klaszi, Scortea tecta, S. hamoza, C. pannuceus, Subtilisphaera senegalensis and Oligosphaeridium complex were recorded in Albian sediment by different authors (Schrank and Ibrahim, 1995; El Shamma et al., 1997; El Shamma et al., 1999 and Mahmoud et al., 1999). Cretacaeiporites polygonalis was recorded in L. Albian - M. Cenomanian deposits of the Atlantic coast basins of West Africa in Senegal and the Ivory Coast. (Jardine and Magloire, 1965).

Correlation: This zone can be correlated with Araucariacites australis of El Shamma et al., (1997) in Hayat- 4 well northern western Desert, Al.1 zone (Araucariacites australis Assemblage Zone) of Bassiouni et al., 1992. and A. australis Acme Zone of El Shamma et al., 1999, Sequence XI (early-mid Albian) of Jardiné and Magloire (1965), Senegal Basin, Zone I (early-mid Albian) of Herngreen (1973) in the 1-QS-1-MA well, Maranhao Basin, Brazil, Zone I (early-mid Albian) of Sultan and Aly (1986), in the WD-9-15-1 well, northern Western Desert, Egypt. Lower part of the Zone V (Albian) of El-Beialy et al. (1990) in the Sindy-1 well, Nile Delta, Egypt and Zones II and III (early-mid Albian) of Schrank and Ibrahim (1995), in the Kahraman-1 well, northern Western Desert, Egypt. Lower part of Zone IV (Albian) of Mahmoud et al. (1999), in the Ramis-1X and Shaltut-1X wells, northern Western Desert, and in the Misri-1 well, 
Northern Sinai, Egypt. Lower part of the Zone PSII (Albian) of Mahmoud and Moawad (2002) in the Sanhur-1X well, northern Western Desert, Egypt. Sequences X-VIII (late Albianearly Cenomanian) of Jardiné and Magloire (1965), Senegal Basin. Zone II (late Albianearly Cenomanian) of Herngreen (1973), in the 1-QS-1-MA well, Maranhao Basin, Brazil. Subzone Ia (late Albian-early Cenomanian) of Lawal and Moullade (1986), upper Benue Basin, northeast Nigeria and Zone I (late Albian-early Cenomanian) of Sultan and Aly (1986) in the WD-9-15-1well, northern Western Desert, Egypt. Zone III (late Albianearly Cenomanian) of Aboul Ela and Mahrous (1992), in the East Tiba-1 well, northern Western Desert, Egypt. Zone 5 (late Albianearly Cenomanian) of Schrank (1992), Egypt and north Sudan. Intervals 3 and 4 (late Albianearly Cenomanian), in the Manndra 1 well and intervals $\mathrm{c}$ and $\mathrm{d}$ (late Albian-early Cenomanian), in the Oued Melah 1 well of Foucher et al., (1994), Algeria. Zone IV (late Albian-early Cenomanian?) of Schrank and Ibrahim (1995), in the Kahraman-1 well, northern Western Desert, Egypt and Assemblage "A" (late Albian-early Cenomanian) of Ibrahim (2002b), in the Abu Gharadig-5 well, northern Western Desert, Egypt.

\section{D3: Pseudoceratium anaphrissum-}

Mudrongia simplex - Cribroperidinium edwardsii Assemblage Zone.

Definition: This zone is defined by the occurrence of Pseudoceratium anaphrissum, Mudrongia simplex and Cribroperidinium edwardsii

Occurrence: This zone extends over the core sets 4-9 (8657-11603 ft., thickness 2946 ft.) in BAX-1 well, core sets 6-10 (14390-8525 $\mathrm{ft}$., thickness $5765 \mathrm{ft}$.) in MMX-1 and core sets 4-6 (10202-8452 ft., thickness 1720) in MAX1.

Age diagnosis: The Barremian age is documented by the first appearance of Pseudoceratium anaphrissum as also recorded from northern England and northwest Europe (Davey, 1974, 1979); and from BarremianEarly Aptian of Egypt (Ibrahim \& Schrank, 1996). Barremian (El Shamma et al., 1997; El Shamma et al., 1999; Ibrahim et al., 2002). Mudrongia simplex is one of the important Barremian species, because it has an uppermost appearance level in the late Barremian, Srivastava, (1984) in SE France; Thusu et al., (1988) in NE Libya; Ibrahim \& El Beialy (1995); Ibrahim \& Schrank (1996); El Shamma et al., (1997) El Shamma et al., (1999); and Ibrahim et al., 2002 from Egypt.

Cribroperidinium edwardsii was recorded from the Barremian of occupied Palestine (Brenner, 1974), NE Libya (Thusu et al., 1988; Uwnis \& Batten, 1988), and in Egypt (Ibrahim \& El Beialy, 1995; Ibrahim \& Schrank 1996; El Shamma et al., 1997 El Shamma et al., 1999 and Ibrahim et al., 2002).

An assemblage of Cribroperidinium edwardsii, Mudrongia simplex and Pseudoceratium anaphrissum is recorded in Barremian - late Hauterivian from NE Libya (Thusu et al., 1988 and Uwnis \& Batten, 1988), and from Egypt (Ibrahim \& El Beialy, 1995; Ibrahim \& Schrank 1996; El Shamma et al., 1997 El Shamma et al., 1999 and Ibrahim et al., 2002).

Correlation: (1) It is similar to the Barremian assemblage recognized by Ibrahim et al. (1995). (2) It is Also Similar to Aptea anaphrassia (now Pseudoceratium anaphrissum) Assemblage Zone described by Thusu et al. (1988) of Barremian age. (3) It is also similar to Zone PS1 and the upper part from the strata of Malha-1 well, north Sinai (Ibrahim \& El Beialy, 1995). (4) It is correlatable with the zone II and III of the Kahraman-1 well, north Western Desert (Ibrahim \& Schrank, 1996), based on several similar species. (5) It is very similar to Zone 3 described by Ibrahim et al., (2002). (6) Br: Pseudoceratium anaphrissum Acme Zone of El Shamma et al.,1999. 


\section{D2: Cribroperidinium edwardsii- Peseudoceratium securigerum Assemblage Zone.}

Definition: This zone is defined by the occurrence of Cribroperidinium edwardsii and Peseudoceratium securigerum.

Occurrence: This zone confines the core set 3 (8372-8310 feet, 62 feet thickness) in the BAX-1, core set 3-5 (4788-7871 feet, 3083 feet thickness) in MMX-1 and core set 3 (67706749 feet, 21 feet thickness) in the MAX-1 well.

Age diagnosis: Pseudoceratium securigerum has a known range from early to Late Aptian in France (Davey \& Verdier, 1974); NE Libya (Uwnis \& Batten, 1988); Egypt (Omran et al., 1990; El Beialy, 1994a; Schrank \& Ibrahim, 1995; and Ibrahim et al., 1995). The base of the range of Subtilisphaera senegalensis is in the Lower Aptian of Senegal (Jain \& Millepied, 1973); Morocco (Below, 1984) and NW Egypt (Schrank \& Ibrahim, 1995).Cribroperidinium orthoceras and Cribroperidinium edwardsii are distinctive markers for Aptian age (Omran et al., 1990; ElBeialy, 1994a; Schrank \& Ibrahim, 1995; Ibrahim et al. 1995; El Shamma et al., 1997; El Shamma et al., 1999; Ibrahim et al., 2002).The assemblage of Oligosphaeridium complex, Subtilisphaera perlucida, Pseudoceratium securigerum, and Cribroperidinium orthoceras is considered to be of Aptian age (Omran et al., 1990; El-Beialy, 1994a; Schrank \& Ibrahim, 1995; Ibrahim et al. 1995; El Shamma et al., 1997; El Shamma et al., 1999; Ibrahim et al., 2002).

Correlation: This zone can be correlated with (1) Aptian Palynofloras (D2) which was described by Omran et al., (1990) from Fadda-1 and Minqar-IX boreholes, northern Western Desert, Egypt. (2) The present assemblage is similar to Dinoflagellate Zone 1 of Schrank \& Ibrahim, (1995). (3) similar dinoflagellate cysts are reported by Ibrahim et al., (1995) in N Egypt and NE Libya. (4) It is similar to dinofelagellate zone 2 of Ibrahim et al., (2002) in northern Eastern Desert, Egypt.

\section{Paleoecology:}

The palynomorphs can be divided into two major groups (1) terrestrial palynomorphs (e.g. spores and pollens) and (2) marine palynomorphs (e.g. dinoflagellate cysts and foraminiferal test lining. The terrestrial palynomorphs indicate the climate that prevailed during the deposition. On the other hand, marine dinoflagellate cysts indicate the marine incursion. The relative abundance of these palynomorphs is illustrated in Figs 2-4.

In the palynomorphs ternary plot (MSP; microplankton-spore-pollen, Federova, 1977 and Duringer and Doubinger, 1985), the samples of the studied wells occupy the deltaic field, Fig. 5. The samples are enriched with a species of spores (Cyathidites, Deltoidospora and Dictyophyllidites) and pollen grains Araucariacites australis and Classopollis classoides). These spores are known to thrive in warm humid to semi-arid climate (Schrank, 1987; Thusu et al. 1988; Schrank and Mahmoud, 1998). In addition, the presence of the species of the hygrophilous palynomorphs (mainly fern spores) such as Deltoidspora, Cicatricosisporites and Concavissimisporites some of the studied samples probably reflects local pteridophyte vegetation and wet lowlands (Playford 1971; Schrank and Mahmoud 1998; Atta-Peters and Salami 2006; El-Soughier et al. 2013). Pteridophytes are known to thrive in wet lowlands, such as riversides and coastal areas (Pelzer et al. 1992; Abbink et al. 2004). The abundance araucaracean pollen reflects conifer vegetation on relatively dry hinterlands (Shrank and Mahmoud 1998; Schrank 2001; Atta-Peters and Salami 2006; El- Soughier et al. 2010, 2013). Therefore, a regional warm and semiarid palaeoclimate is suggested to prevail during deposition of the studied sediments but with a local humid condition developed near or at the site of the wells. Some samples locally show relatively higher abundances with marine microplankton (dinoflagellates and foraminiferal test lining), these samples are plotted in the shallow marine to open marine conditions. 


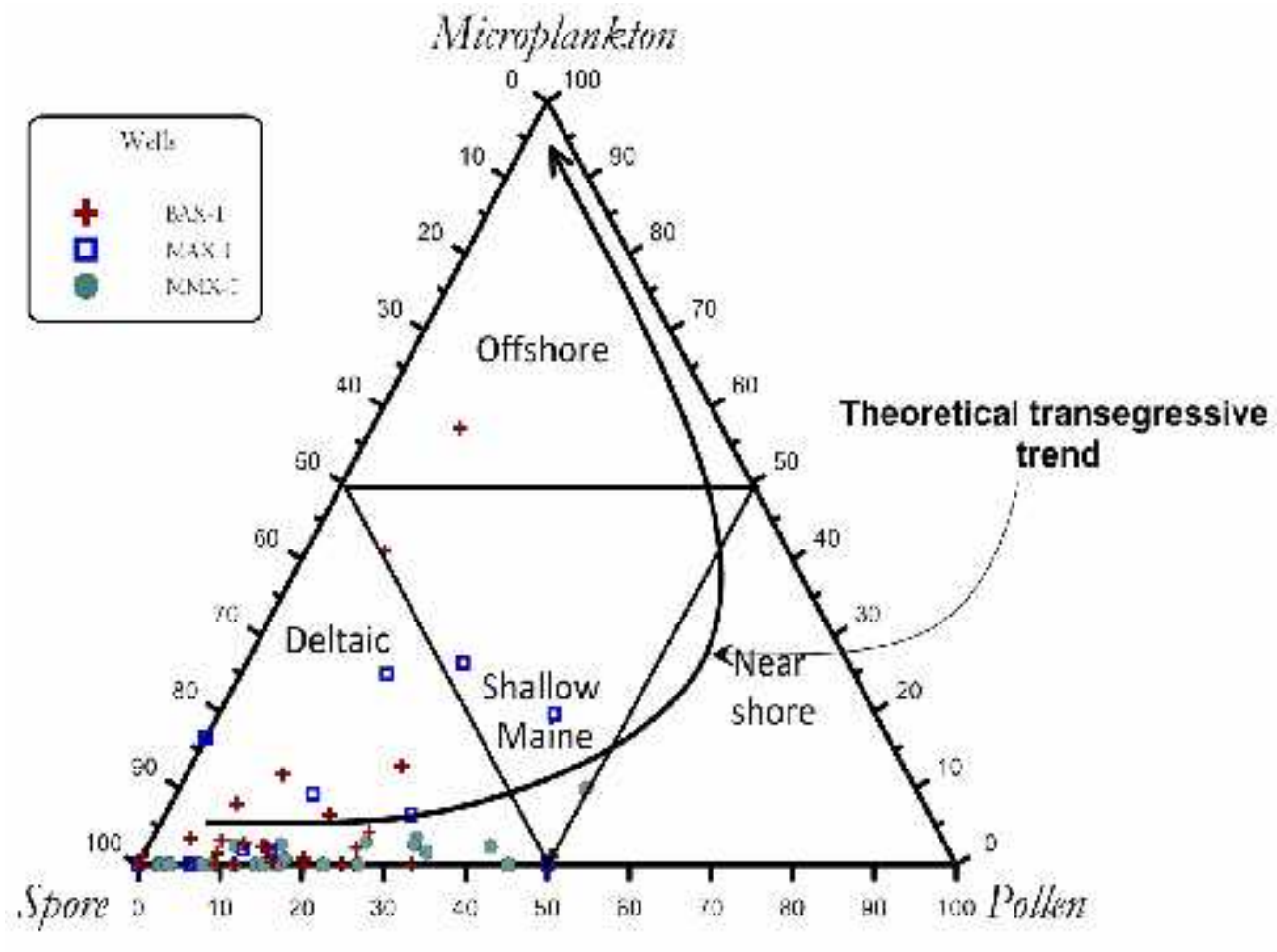

Fig.5. Ternary Microplankton-Spore-Pollen palynomorph plot of Lower Cretaceous succession in the studied wells (after Tyson, 1993 and 1995).

\subsection{Kharita Formation (Albian):}

Miospore Assemblage of the Kharita Formation is characterized by high abundance of Cyathidites and Araucariacites. The Araucariacites is characteristic of humid and subtropical to tropical climates, (Tschudy in Peterson, 1969a). The occurrence of the fern spores represented by pteridophytes (e.g. mainly Deltoidospora) in all studied samples probably reflects local pteridophyte vegetation on wet lowlands (Playford, 1971; Schrank and Mahmoud, 1998).However, on the relatively dry hinterlands, conifer forests arethought to develop based on the presence of the araucariacean pollen grains Arucariacites spp. (Schrank and Mahmoud, 1998 Mahmoud and Moawad, 2002).The Kharita Formation is characterized by high abundance of Oligosphaeridium which indicate an openmarine (inner-neritic), warmer and/or deeper shelf water environment, (Downie et al., 1971; Marshall \& Batten, 1988). Consequently, a humid and warmer climate prevailed during the Albian time.

\subsection{Dahab and Alamein formations (Aptian):}

These formations are characterized by high abundance of Cyathidites, Cicatricosisporites and Araucariacites gymnosperm, Afropollis angiosperm and Cribroperidinium dinoflagellate. Afropollisis the most abundant angiosperm pollen genus in the successions. This genus is interpreted as of typical tropical to subtropical environments (Doyle et al., 1982).

Cribroperidinium is suggested to reflect inner shelf environment (Harding, 1982). The Cicatricosisporites assemblage occur in the middle and upper seam and probably derived from a freshwater herbaceous mire community. The occurrence of some peridinioid cysts and foraminiferal test linings suggests that both inner and middle shelf deposits are represented as reported by El Beialy and Al-Hitmi (1994) from the Cretaceous of Qatar. Consequently, the deposition takes place in shallow to inner shelf environments and under humid climatic conditions. 


\subsection{Alam El Bueib Formation (Barremian- Neocomian):}

The miospore assemblage of the Alam El Bueib Formation is characterized mainly by the occurrence of Cyathidites, Pilosisporites, Concavissimisporites, Crybelosporites, Cicatricosisporites and Triloposporites which represent the main constituents of the assemblage. Generally, high abundance of these spores is recorded in near shore environments (Tyson, 1995). These groups of trilete spores comprised relatively heavy, mainly transported palynomorphs. Therefore, the frequency of this group is possibly inversely proportion to the distance from river mouths and shorelines. Classopollis pollen grains are known to be produced by xerophyte plants; their high abundances are taken to indicate arid climatic conditions(Watson, 1988; Doyle, 1999).The high abundance of Crybelosporites suggests a freshwater environment. Dinoflagellate assemblage is represented mainly by Escharisphaeridia, Oligosphaeridium and Cribroperidinium. The abundance of hygrophilous palynomorphs (e.g. Deltoidospora and Cicatricosisporites) inmost samples reflects pteridophytic vegetation that grew on moistbiotopes under fairly humid conditions (Schrank, 1987; Schrankand Mahmoud, 1998). Conifer forests with Araucariacites/Inaperturopollenites are thought to have flourished in the relativelydry hinterlands at some horizons. The considerable percentage of the terrestrial microspores indicates that the deposition was very close to the land (terrestrial environment) where the dinoflagellate cysts percentage is low. Consequently, the miospore assemblage indicates that humid climate condition prevailed during the deposition. Whereas the din flagellate assemblage indicates to most common in stable marine environments; innerneritic and restricted marine; marginal-marine (deltaic); warmer and/or deeper shelf water (Downie et al., 1971; Marshall \& Batten, 1988).

\section{SUMMERY AND CONCLUSIONS:}

The palynologic examination of 144 core samples collected from the Neocomian -
Albian Kharita, Dahab, Alamein, Alam El Bueib formations in MAX-1, BAX-1 and MMX-1 wells in the northern part of the Western Desert led to the recognition of a diverse and well preserved palynomorphs association. 147 species belonging to 102 genera of palynomorphs have been identified in the present work. These consist of 62 species belonging to 38 genera of spores, 39 species belonging to 26 genera of gymnosperm pollen, 13 species belonging to 11 genera of angiosperm, 13 species belonging to 13 genera of freshwater algae, 1 species belonging to acritarchs and 19 species belonging to 13 genera of dinoflagellates. Five informal palynozones are identified, fully described and dated from the studied interval of the three studied wells. These are:

I- Impradecispora apiverrucataAequitriradites spinulosus Assemblage Zone. (Berriasian - Barremian age).

II- Murospora florida - Concavissimisporites variverrucatus - Afropollis operculatus Assemblage Zone. (Aptian age).

III- Araucariacites australis Acme Zone. (Albian age).

IV- Pseudoceratium anaphrissum- Mudrongia simplex - Cribroperidinium edwardsii Assemblage Zone. (Barremian age).

V- Cribroperidinium edwardsii-

Peseudoceratium securigerum Assemblage

Zone. (Aptian age).

The above palynozones are also correlated with other selected contemporaneous palynozonations from Egypt and northern Gondwana regions.

According to the relative abundances and paleoecologic characters of the palynomorphs, the Kharita Formation maybe deposited in an open-marine (inner-neritic), warmer and/or deeper shelf environment and humid and warmer climate. The Dahab and Alamein formations maybe deposited in a shallow to inner shelf environment and under humid, tropical to sub-tropical climatic conditions. The Alam El Bueib Formation maybe deposited in marginal-marine (deltaic); warmer and/or deeper shelf environment under humid climatic conditions. 


\section{Plate 1}
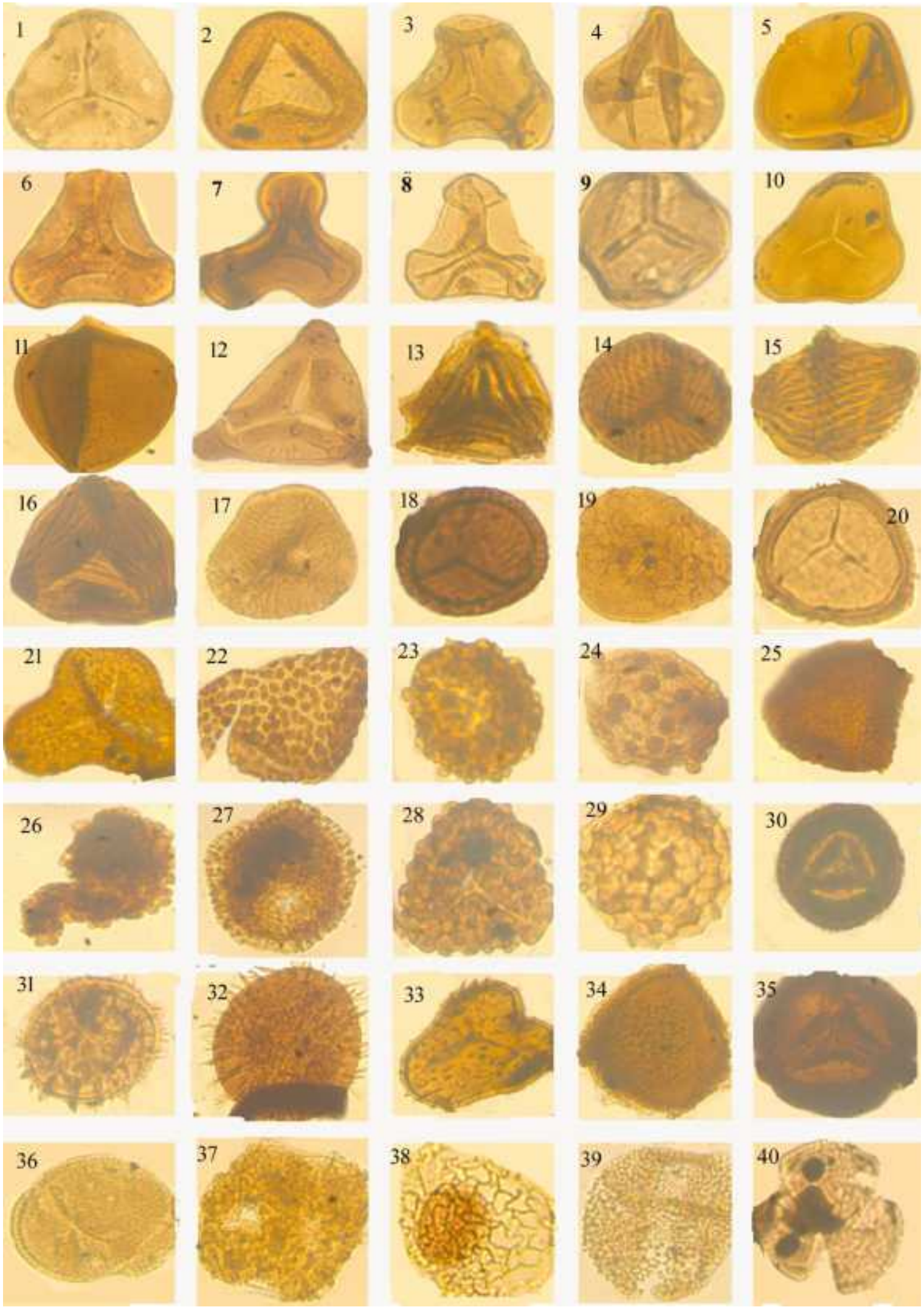


\section{Plate 2}
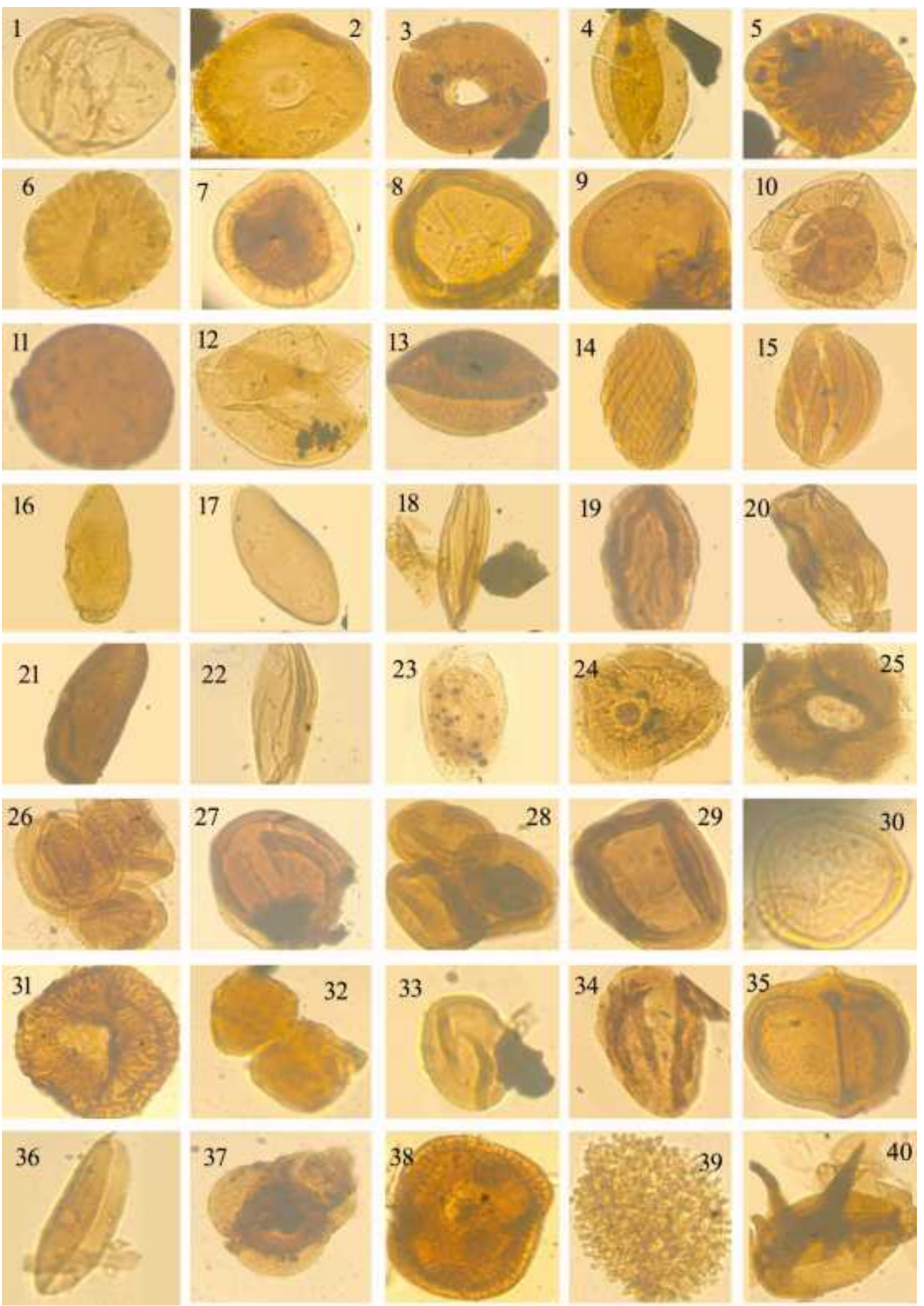

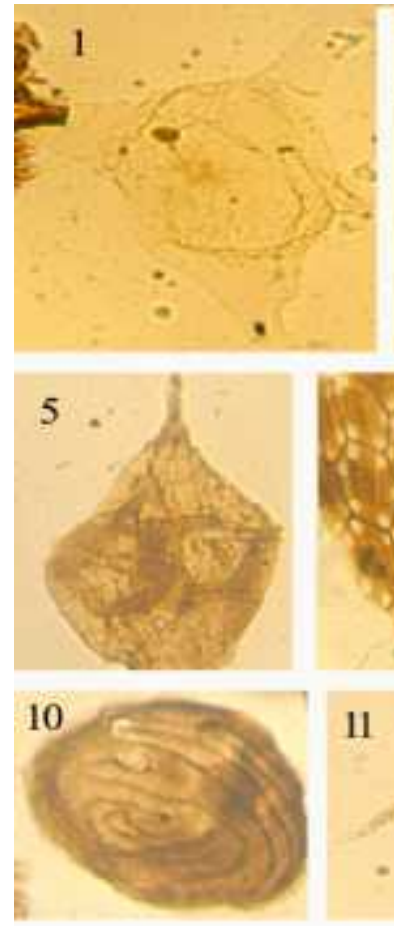
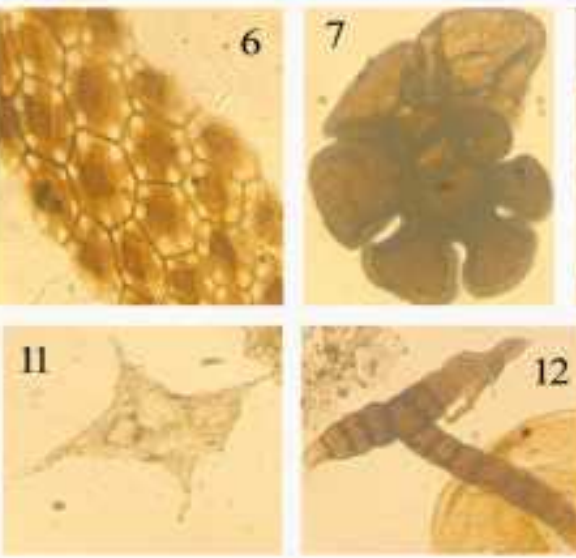

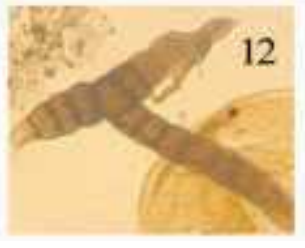

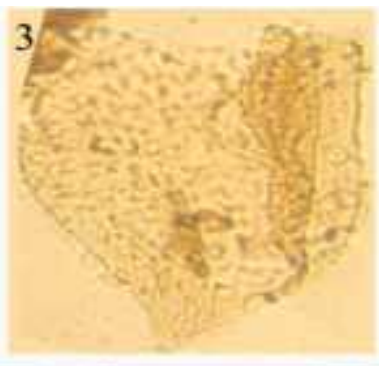
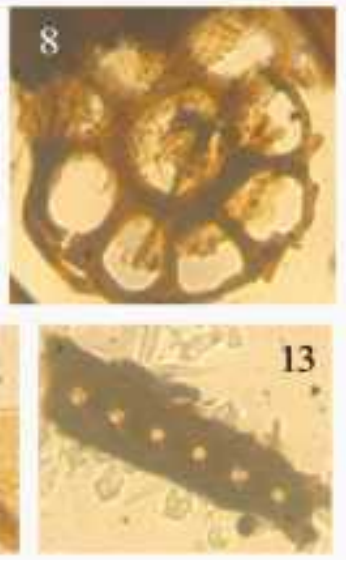
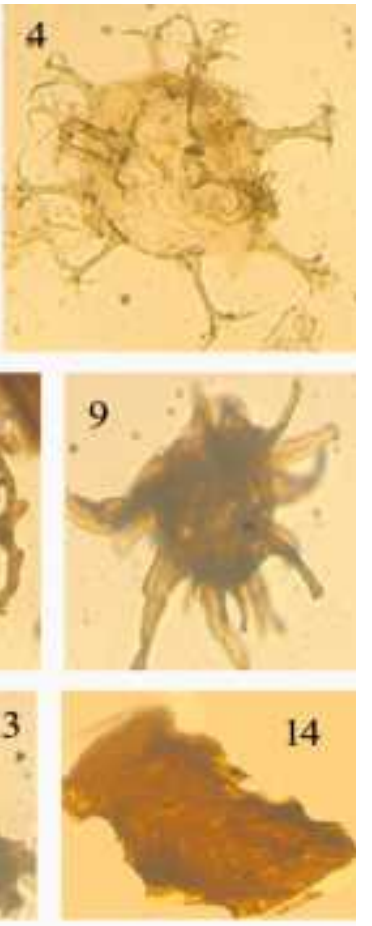

\section{Plate 1}

1- Cyathidites minor Couper 1953, Mmx-1, 12080 feet, 48 m.2- Cyathidites australis Couper 1953, Mmx-1, 5915 feet, 44 m.3 - Cibotiumspora jurienensis (Balme 1957) Filatoff, 1975, Mmx-1, 7881 feet, 38 m.4 - Deltoidospora hallii Miner 1935, Mmx-1, 10476 feet, 48 m.5 - Dictyophyllidites harrisii Couper 1958, Mmx-1, 4798 feet, 58 m. 6 - Gleicheniidites senonicus Ross emend. Skarby 1964, Mmx-1, 5915 feet, 37 m.7 - Concavissimisporites sp. Thusu and Van der Eem1985, Mmx-1, 8815 feet, 51 m. 8 - Concavisporties jurienensis Balme 1957, Mmx-1, 5906 feet, 36 m.9Todisporites minor Couper1958, Mmx-1, 10607 feet, 38 m.10 -Concavissimisporites punctatus Brenner 1963, Mmx-1, 5906 feet, 64 m.11- Triplanosporites sp. Bax-1, 10002 feet, 54 m.12Matonisporites simplex Deak 1964, Bax-1, 7188 feet, 65 m.13- Appendicisporites potomacensis Brenner 1963, Mmx-1, 7067 feet, 45 m.14- Cicatricosisporites orbiculatus Singh 1964, Mmx-1, 8815 feet, 28 m.15-Cicatricosisporites venustusDeak 1963, Bax-1, 8392 feet, 32 m.16-Cicatricosisporites australiensis (Cookson) Potonie 1956, Bax-1, 10025 feet, 47 m. 17-Cicatricosisporites sinuosus Hunt 1985, Bax-1, 10025 feet, 37 m.18- Rogalskaisporites cicatricosus (Rogalska) Danzd - Corsin and Laveine, 1963 in Briche et al. 1963, Bax-1, 8374 feet, 22 m.19-Triporoletes reticulates (Pocock) Playford 1971, Mmx-1, 7412 feet, 58 m.20-Cingutriletes clavus (Balme) Dettmann1963, Bax-1, 11618 feet, 32 m.21 - Concavissimisporites variverrucatus (Couper) Brenner 1963, Mmx-1, 5915 feet, 50 m.22 - Foraminisporis asymmetricus Cookson and Dettmann 1970 Mmx-1, 7067 feet, 52 m.23 Gemmatriletes densegemmatus Brenner1974, Mmx-1, 5930 feet, 32 m.24 - Clavatisporites clarus Kedves 1971, Mmx-1, 4798 feet, 29 m.25 - Klukisporites sp. Couper 1958, Mmx-1, 7067 feet, 55 m.26 - Reyrea polymorpha Herngreen 1973, Mmx-1, 8815 feet, 50 m.27 - Rousea brenneri Singh 1983, Mmx-1, 4798 feet, 75 m.28 - Verrutriletes sp. Mmx-1, 9516 feet, 31 m.29 - Raistrickia sp. Mmx-1, 7067 feet, 29 m.30 - Densoisporites perianatus Weyland and Krieger 1953, Mmx-1, 5915 feet, 24 m.31 - Apiculatisporis sp. Mmx-1, 5906 feet, 29 m.32- Pilosisporites cf. trichopapillosus (Thiegart) Delcourt and Sprumont 1955, Bax-1, 11618 feet, 56 m.33 - Pilosisporites verus Delcourt and Sprumont 1955, Mmx-1, 5906 feet, 42 m.34 - Aequitriradites verrucosus (Cookson and Dettmann) Cookson and Dettmann 1961, Mmx-1, 5930 feet, 51 m.35 - Murospora florida (Balme) Pocock 1961, Mmx-1, 10607 feet, 64 m.36- Tricolpites micromunus (Groot and Penny) Singh 1971, Mmx-1, 6724 feet, 34 m.37- Cretacaeiporites scabratus Herngreen 1974, Bax-1, 7188 feet, 56 m.38Afropollis jardinus (Brenner) Doyle, Jardiné and Doerenkamp 1982, 4798 feet, 28 m.39Retimonocolpites variplicatusSchrank and Mahmoud 1998, Mmx-1, 4798 feet, 44 m.40- Tricolpites micromunus (Groot and Penny) Singh 1971, Bax-1, 8716 feet, $26 \mathrm{~m}$. 


\section{Plate 2}

1- Araucariacites australis Cookson and Couper 1953, Bax-1, 8363 feet,60 m.2-Zonalaplicites aegyptiaca Saad and Ghazaly 1976, Mmx-1, 4798 feet,58 m.3- Balmeiopsis limbatus (Balme)Archangelsky 1979, Mmx-1, 5915 feet,64 m.4- Bennettiteaepollenites regaliae Schrank 1998, Mmx-1, 5918 feet, 63 m. And38 m.5, 6-Callialasporites dampieri (Balme 1957) Dev 1961, Mmx-1, 5- 4798 feet, 47 m., 6- 7412 feet, 37 m.7- Callialasporites discoidalis Döring) Bharadwaj and Kumar 1972, Mmx-1, 5915 feet, 46 m.8- Cingulatipollenites sp. Mmx-1, 6724 feet, 41 m.9Circulina parvaBrenner 1963,Mmx-1, 5918 feet, 51 m.10-Callialasporites discoidalis (Döring) Bharadwaj and Kumar 1972, Bax-1, 11643 feet, 55 m.11- Spheripollenites psilatus Couper 1958, Mmx-1, 4798 feet, 26 m.12,13- Cycadopites carpentieri (Delcourt and Sprumont) Singh 1964, Mmx1, 12- 5930 feet, 63 m., 13- 7875 feet, 41 m.14- Ephedripites jansonii Muller 1968, Mmx-1, 5930 feet, 41 m. and 26 m.15- Ephedripites ovalisMuller 1968, Mmx-1, 5930 feet, 40 m. and 27 m.16Ephedripites regularisvan Hoeken-Klinkenberg 1964, Mmx-1, 5930 feet, 107 m. and46 m.17Laevigatosporites ovatus Wilson and Webster 1946, Mmx-1, 7881feet, 54 m. and26 m.18- Singhia montanaensis (Brenner) de Lima 1980, Mmx-1, 7875 feet, 63 m.and19 m.19- Ephedripites irregularis Herngreen 1973, Bax-1, 8716 feet, 49 m.20- Equisetosporites concinnus Singh 1964, Bax-1, 10020 feet, 79 m.37 m.21-Steevesipollenites spp. Mmx-1, 10607 feet, 112 m.and 51 m.22- Gnetaceaepollenites sp. Bax-1, 9994 feet, 55 m. and 22 m.23- Steevesipollenites spp. Bax1, 9994 feet, 66 m. and 38 m.24- Crybelosporites vectensisKemp 1970, Bax-1, 10025 feet, 37 m.25- Cretacaeiporites polygonalis Herngreen 1974, Mmx-1, 10815 feet, 50 m.26- Classopollis meyeriana Klaus 1960, Bax-1, 11618 feet, 21 m.27- Classopollis cf. noeli Eeyre 1970, Bax-1, 8716 feet, 31 m.28- Classopollis classoides Pflug 1953, Bax-1, 8680 feet, 20 m.29- Clavatipollenites hughesii Couper 1958, Bax-1, 11549 feet, 32 m.30- Corollina torosa (Reissinger) Klaus emend. Cornet and Traverse 1975, Bax-1, 11384 feet, 25 m.31- Inaperturopollenites undulatus Weyland and Greifeld 1953, Bax-1, 10025 feet, 91 m.32- Cupressacites oxycedroides Reyre 1973,Mmx-1, 5918 feet, 36 m.33- Eucommiidites minor Groot and Penny 1960, Bax-1, 11384 feet,18 m.34Eucommiidites troedssonii (Erdtman) Couper 1958, Bax-1, 8374 feet,48 m.35- Tricolporopollenites sp. Mmx-1, 5906 feet, 43 m.36- Ovoidites parvus (Cookson and Dettmann) Nakoman 1966, Bax-1, 11643 feet, $48 \mathrm{~m}$. and 15 m.37-psilatricolpites tetradus Brenner 1968, Bax-1, 11635 feet, 30 m.38- Cretacaeiporites densimurus Schrank and Ibrahim1995, Bax-1, 7188 feet, 56 m.39Stellatopollis dejaxii Ibrahim 2002, Bax-1, 10025 feet, 52 m.40- Elaterosporites sp. Mmx-1, 5906 feet, $58 \mathrm{~m}$.

\section{Plate 3}

1-Muderongia tetracantha Alberti 1961, Mmx-1, 11618 ft., 42 m.2-Subtilisphaera perlucidaAlberti, 1959b, Mmx-1, 5906 ft., 45 m.3-Psudoceratium securigerum Bint 1986, Mmx-1, 9994 ft., 52 m.4Oligosphaeridium complex Davey 1969, Mmx-1, 5906 ft., 31 m.5-Cribroperidinium edwardsii Davey 1969, Mmx-1, 10010 ft., 58 m. 6- Part of a tracheid showing alternate bordered pits.7Planespiral benthonic Foraminiferal test lining, Mmx-1, $10815 \mathrm{ft} .8$ - Vederosella alimani Dragastan 1999, Mmx-1,5906 ft.9- Cercospora sp.Mmx-1, 10607 ft.10- Chomotriletes minor (Kedves) Pocock1970, Mmx-1, 10476 ft.11- Veryhachium collectumWall1965, Mmx-1, 10607 ft.12- Alternaria porri(Ellis) Cif 1930, Mmx-1, $7412 \mathrm{ft}$. 13- Tracheids with uniseriate bordered pits, Mmx-1, 10815 ft.14- Tracheids with biseriate opposite bordered pits, Mmx-1, $7067 \mathrm{ft}$. 


\section{REFERENCES}

Abdelmalik, W. M., Aboul Ela, N. M. and ElShamma, A.A. (1981): Upper JurassicLower Cretaceous microfloras from the North Western Desert, Egypt. - N. Jb. Geol. Palaeont., Abh. 162, 244-263.

Aboul Ela, N. M. (1979): Lower Cretaceous microflora from the North Western Desert of Egypt. - N. Jb. Geol. Palaeont. Mb., 10, 586595.

Awad, M. Z. (1994): Stratigraphic, Palynological andpalaeoecological studies in the eastcentral Sudan (Khartoum and Kosti Basins), Late Jurassic to MidTertiary. Berl. geowiss. Abh., Rh. A., 161, 1 - 163.

Baioumi, A. A. (2002): Late Jurassic - Early Cretaceous palynomorphs from El mazar -1 well, north Sinai, Egypt. Egypt. J. Paleontol., $2,385-397$.

Barakat, M. G. and Darwish, M. (1987): Contributions of the lithostratigraphy of the Lower Cretaceous sequence in Mersa Matruh area, North Western Desert Egypt. - M. E. R. C. Ain Shams Univ. Earth Sci. Series, 1. 4866.

Bassiouni, E. M., El-Shamma, A. A., and Baioumi, A. A. (1992): Study of the microfloral characteristics of Aptian Cenomanian sediments in WD-38-1 well, Western Desert, Egypt. - Bull. Fac. Sci., Alex. Univ., 32(A), 466-483.

Brenner, G. J. (1963): The spores and pollen of thePotomac Group of Maryland. Geol. Dept., Mines andWater Resources Bull., 17, 1-215.

Delcourt, A. and Sprumont, G. (1955): Les spores etgrains de pollen du Wealdien du Hainaut. Mém.Soc. Beige. Géol. Paléont. Hydro. 4, 5, $1-73$.

Dettmann, M. E. (1963): Upper Mesozoic microflorasfrom south-Eastern Australia. Proc. Roy. Soc.Victoria n.s.,77, 1,1 - 148.

Downie, C. Lister, T. R., Harris, A. L. and Fettes, D. G. (1971): Apalynological investigation of the Dalradian rocks of Scotland:, inst. Geol. Sci. Rep.71/ 9. London, 29 p.

Doyle, J.A., Jardiné, S., Doerenkamp, A. (1982): Afropollis, a new genus of early angiosperm pollen, with notes on the Cretaceous palynostratigraphy and paleoenvironments of northern Gondwana. Bull Cent Rech Expl Prod Elf-Aquitaine 6, 39-117.

El Beialy, S. Y. (1994): Early Cretaceous dinoflagellate cysts and miospores from the Mersa Matruh I borehole, Western Desert, Egypt, Qatar Univ. Sci. J., 14 (1), 184 - 200.
El Beialy, S. Y., Ayyad, S. N. and Kholeif, S. E. (1990): Mesozoic-Tertiary palynomorphs and planktonicforaminifera of the subsurface section of the Sindy-1 well, eastern Nile Delta, Egypt. Newsl. Stratigr.,22 (2/3), 71-85.

El Beialy, S.Y., El Atfy, H.S., Zavada, M.S., El Khoriby, E.M., Abu-Zied, R.H. (2010a): Palynological, palynofacies, paleoenvironmental and organic geochemical studies on the Upper Cretaceous succession of the GPTSW-7 well,North Western Desert, Egypt. Marine and Petroleum Geology 27, 370-385.

El Beialy, S.Y., El-Soughier, M.I., Abdel Mohsen, S., El Atfy, H.S., (2011): Palynostratigraphy and paleoenvironmental significance of the Cretaceoussuccession in the Gebel Rissu-1 well, north Western Desert, Egypt. Journalof African Earth Sciences 59, 215-226.

El Gezeery, N. H. and O' Connor, T. (1975): Cretaceous rock units of the Western Desert Egypt.Egypt - Ann. Meet., Geol. Soc., 2p.

El-Shamma, A. A. (1988): Aptian and Albian miozones of the Western Desert, Egypt. - 9th Pet. Conf. Explor. Prod., E. G. P. C., 1-21.

El-Shamma, A. A. and Arafa, A. A. (1988): Early pollenangiosperm from the Lower Cretaceous sediments inthe northern part of the Western Desert, Egypt. -Egypt. J. Geol., 32 (1-2), 263272.

El-Shamma, A. A. and Baioumi, A. A. (1993): Palynostratigraphic zonation of northern WesternDesert, Egypt. - Egypt. J. Geol., 35(1-2), 261-273.

El-Shamma, A. A., Obeid, F. L. and Mohammed, S. A. (1999): Neocomian-Cenomanian palynozones of some subsurface rocks in north Western Desert, Egypt. - 1st International Conference of Geology of Africa, 1, 65-102.

El Shamma, A.A., Zein El Din, M.Y. and Mohammed,S.A., (1997): Additional study on microfloralcharacteristics and palynozones of subsurfaceCretaceous Rocks in the Western Desert, Egypt.Bull. Facult. Sci., Assiut Univ. 26(2-F), 1 - 28.

El Sheikh, H. A. and Aly, S. M. (1994): Biostratigraphicstudy on the Jurassic-Early Cretaceous rocks insome exploratory wells in north Sinai, Egypt.Egypt. J. Geol. 38 (2), 507 -524 .

Hantar, G. (1990): North Western Desert. In: Said $\mathrm{R}$ (ed.) The Geology of Egypt, chapter 15. Balkema, New York. 293-319. 
Harding, S. (1982): the science question in feminism.Ithaca, N.Y. Cornell University press.

Herngreen, G. F. W. (1973): Palynology of Albian-Cenomanian strata of borehole 1-QS1-MA, State of Maranhao, Brazil. Poll.Spor., 15 (3-4), 515-555.

Ibrahim, M. I. A., Aboul Ela, N. M. and Kholeif, S. E. (2002): Dinoflagellate cyst biostratigraphy ofJurassic- Lower Cretaceous formations of the NorthEastern Desert, Egypt. - N. Jb. Geol. Palaeont. Abh.,224(2), 255-319.

Ibrahim, M. I. A., Aboul Ela, N. M. and Kholeif, S. E. (2001): Palynostratigraphy of Jurassic to Lower Cretaceous sequences from the Eastern Desert of Egypt. - J. Afr. Earth Sci., 32(2), 269-297.

Ibrahim, M. I. A., El Beialy, S. Y. (1995): Kimmeridgian - $\quad$ Barremian palynostratigraphy of the Malha-1 well,North Sinai, Egypt. - Sci. Géol. Bull., 48 (4): $187-$ 209.

Ibrahim, M. I., Schrank, E. (1996): Palynological studieson the Late Jurassic - Early Cretaceous of theKahraman-1 well, northern Western Desert, Egypt. -Géologie de l'Afrique ET de l'Atlantique sud: ActesColloques Angers 1994, 611 - 629.

Ied, I. M. and Lashin, G.M.A. (2016): Palynostratigraphy and paleobiogeography of the Jurassic - Lower Cretaceous succession in Kabrit-1 well, northeastern Egypt. Cretaceous Research 58, $69-85$.

Jardiné, S. (1967): Spores à expansions en formed'élatères du Crétacé moyen d’Afrique occidentale.Rev. Palaeobot. Palynol., 1, 235258.

Kora, M. and El Beialy, S. (1989): Early Cretaceous palynomorphs from Gabal Musaba Salama area, southwestern Sinai, Egypt. Rev. Palaeobot. Palynol., 58, 129-138.

Mahmoud, M. S. and Deaf, A. S. (2007): Cretaceous Palynology (spores, pollen and dinoflagellate cysts) of the Siqeifa1-X Borehole, Northern Egypt. -Rivista Italiana di Paleontologia e Stratigrafia,133(2), 203-221.

Mahmoud, M. S., DeafA. S., TamamM. A., Khalaf, M. M. (2017): Palynofacies analysis and palaeoenvironmental reconstruction of the Upper Cretaceous sequence drilled by the Salam-60 well, Shushan Basin: Implications on the regional depositional environments and hydrocarbon exploration potential of north-western Egypt.
Revue de micropaléontologie 60 (2017) 449467

Mahmoud, M. S. and Moawad, A. M. M. (2002): Cretaceous palynology of the Sanhur-IX Borehole,North western Egypt. - Revista Espaniola deMicropal., 34(2), 129-143.

Mahmoud, M. S., Omran, A. M. and Ataa, S. A. (1999): Stratigraphy of the Upper JurassicLower Cretaceoussequences from three boreholes, northern Egypt:palynological evidence. - Newsletters onStratigraphy, 37 (3), 141-161.

Makled, W. A. (2004): Palynological and environmental studies on some subsurface Jurassic and Cretaceous rocks in the northern part of the Western Desert, Egypt. - M.Sc. Thesis, Ain Shams Univ., Egypt.

Makled, W. A., Baioumi, A. A. and Saleh, R. A. (2013): Palynostratigraphical studies on some subsurface middle Albian-early Cenomanian sediments from North Western Desert, Egypt. Egypt. J. Petrol. 22, 501-515.

Marshall, K. L and Batten, D. J. (1988): Dinoflagellate cyst associations in Cenomanian - Turonian 'black shale' sequences of north Europe. Rev. Paleopot. Palynol., 54, 85 - 103.

Norris, G. (1969): Miospores from the Purbeck Beds and marine Upper Jurassic of southern England. Palaeont., 12, 574 - 620.

Omran, A. M., Soliman, H. A. and Mahmoud, M. S. (1990): Early Cretaceous palynology of three boreholes from northern Western Desert, Egypt. - Rev. Palaeobot. Palynol. 66, 292-312.

Penny, J. H. J. (1988): Early Cretaceous palynological studies in the north Westen Desert of Egypt. - The Brit. Micropalaeont. Soc. $35,1-8$.

Penny, J. H. J. (1991): Early Cretaceous angiosperm pollen from the borehole Mersa Matruh 1, North Western Desert, Egypt. Palaeont. Abt. B., 222. $31-88$.

Peterson, F. (1969a): Cretaceous sedimentation and tectonism in the southeastern Kaiparowits region, Utah. USGS open file report. 259 pp.

Pocock, S. A. J. (1962): Microfloral analysis and age determination of strata at the Jurassic Cretaceous boundary in the Western Canada plains. Palaeontograph. Bull, 3, 1-95.

Saad, S. I. and Ghazaly, G. (1976): palynologic studies in Nubian Sandstone from Kharga Oasis. - Poll. Spor. 18. 407-470. 
Said, R. (1990): The Geology of Egypt.Balkema. Rotterdam, 733 pp.

Schrank, E. (1984): Paleozoic and Mesozoic palynomorphs from the Foram 1 well (Western Desert, Egypt). - N. Jb. Geol. Paläont., Mh. 2. 95-112.

Schrank, E. (1987): Paleozoic and Mesozoic palynomorphs from northeast Africa (Egypt and Sudan) with special reference to Late Cretaceous pollen and dinoflagellates. Berliner Geowiss. Abh.A., 75(1), 249-310.

Schrank, E. (1990): Palynology of the clastic Cretaceous sediments between Dongola and Wadi Muqaddam, Northern Sudan. - Berliner geowissenschaften Abhandelungen Rh. A., 120(1), 149-168.

Schrank, E. (1992): Nonmarine Cretaceous correlations in Egypt and Northern Sudan palynological and palaeobotanical evidence., - Cret. Res., 13.351-368.

Schrank, E. and Ibrahim M. I. A. (1995): Cretaceous (Aptian - Maastrichtian) palynology of foraminiferadated wells (KRM-1, AG-18) in northwestern,Egypt. Berliner geowissenschaftliche Abhandelungen A., 177, 1-44.

Schrank, E. and Mahmoud, M. S. (1998): Palynology (pollen, spores and dinoflagellates) and Cretaceous stratigraphy of the Dakhla Oasis, central Egypt. - J. Afri. Earth Sci. 26(2), 167-193.

Singh, C. (1964): Microflora of the Lower CretaceousMannville Group, east-central Alberta. Alberta Res.Council, Bull., 15, 1239.

Singh, C. (1983): Cenomanian Microfloras of the Peace River area, northwestern Alberta. Alberta Res. Council, Bull., 44, 1-322.

Sultan, I.Z. (1987): Palynology of Aptian Cenomanian strata in Mersa Matruh well, Western Desert, Egypt. - J. Afr. Earth Sci., 6.665-675.

Tahoun, S. S., Makled, W. A., Mostafa, T. F. and Saleh R. A. (2015): Palynomorph biostratigraphy of the Cretaceous (Hauterivian-lower Cenomanian) of the South Sallum Well, North Western Desert, Egypt. - Arab. J. Geosci., 3. 1-15.

Thusu, B. and van der Eem, J. G. L. A. (1985): Early Cretaceous (Neocomian Cenomanian)Palynomorphs. J. Micropal., 4 (1), 131-150.

Thusu, B., Van der Eem, J. G. L. A., ElMehdawi, A.and Bu-Argoub, F. (1988): Jurassic-Early Cretaceous palynostratigraphy in northeast Libya.In: El-Arnauti, A. et al., eds., Subsurface Palynostratigraphy of northeast Libya, Garyounis Univ. Publ.,171 213.

Traverse, A. (1988): Paleopalynology. Unwin Hyman, Boston., $600 \mathrm{p}$.

Tyson, R.V. (1995): Sedimentary organic matter. Organic facies and palynofacies, Chapman and Hall, London, 615 p.

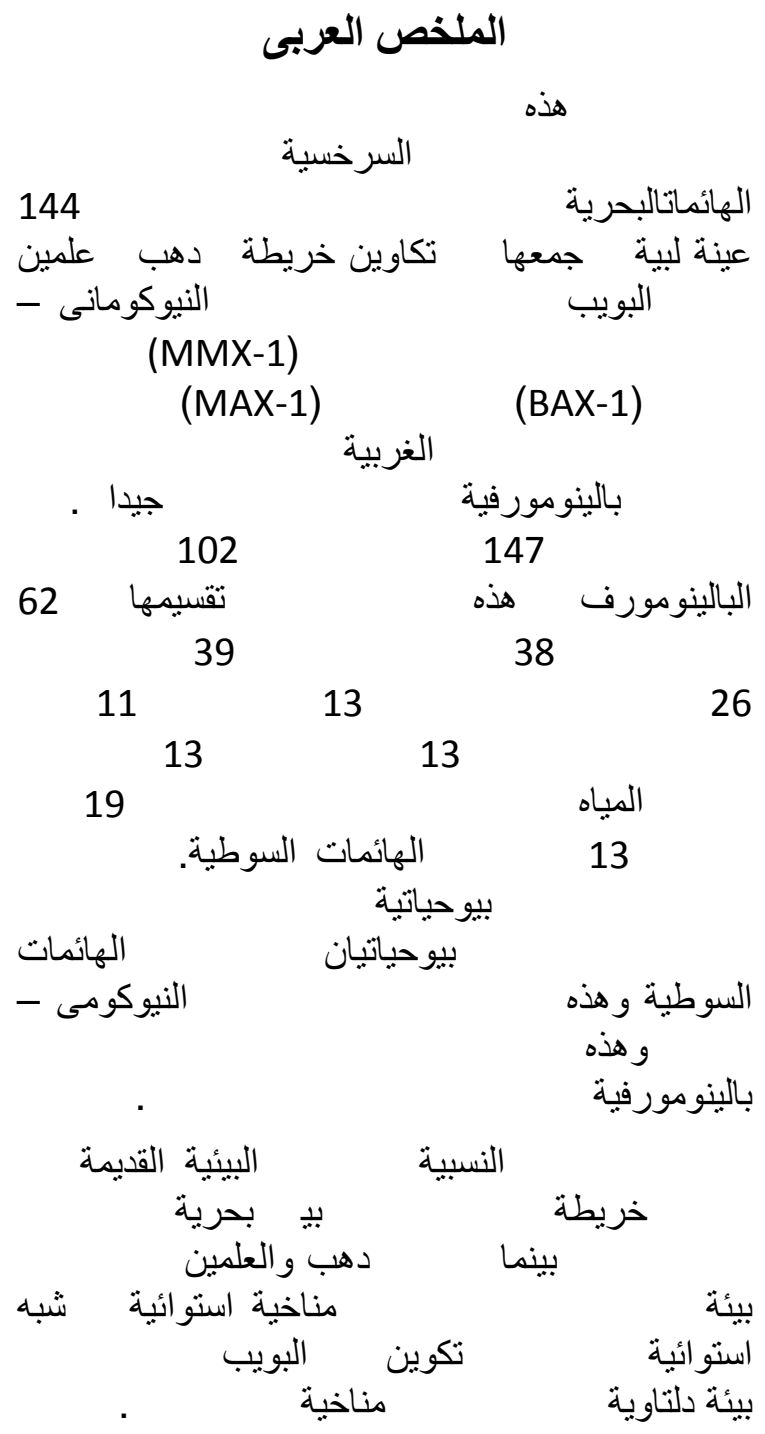

